\title{
ISLAMIC GREEN BANKING AT BANK PEMBANGUNAN DAERAH
} IN INDONESIA

\author{
Rahmayati $^{1}$ \\ Universitas Muhammadiyah Sumatera Utara, Medan, Indonesia \\ rahmayati@umsu.ac.id
}

Siti Mujiatun ${ }^{2}$

Universitas Muhammadiyah Sumatera Utara, Medan, Indonesia sitimujiatun@umsu.ac.id

Maya Sari ${ }^{3}$

Universitas Muhammadiyah Sumatera Utara, Medan, Indonesia mayasari@umsu.ac.id

\begin{abstract}
This research aims to prove the concept of Islamic Green Banking in the banking system in Indonesia, precisely at the Bank Pembangunan Daerah (BPD) bank and to proves that CSR, Green Accounting, Growth Financing, NPF, Liability on Green Banking have a simultaneous and partial test effect on Green Banking. The research method used is descriptive quantitative, using secondary data from the bank's Annual Report from 2015-2020 at PT. BPD Aceh Syariah, PT. BPD Sumatera Utara, PT. BPD Jambi, PT. BPD. Nagari, PT. BPD. Riau and Kepulauan Riau, PT. BPD Sumatera Selatan and Bangka Belitung. The results of the study prove that the Corporate Social Responsibility (CSR), Growth Financing, Green Accounting, NPF variable have an effect on Green Banking except for Liability variable which shown negative result on Green Banking and this study is that the application of Green Banking is a pattern that can be implemented by the BPD through digitizing online services.
\end{abstract}

Keywords: Green Banking, Green Accounting, CSR, Growth Financing 


\section{INTRODUCTION}

Changing the paradigm in the industrial era 4.0 must be adapted to the needs of human life nowadays, innovating in making changes must have an impact on the environment. These problems include the Triple Bottom Line problem, namely Profit, People, and Planet (Green Finance Concept). (Istiowati, 2018).

The difference between financial institutions and the environment should not eliminate the growing integration between the two so that they can synergize with each other, because both have the same commitment and value to build sustainability. Green Banking become a consideration for banking system in Indonesia because there is a concept of sustainable finance formulated by Otoritas Jasa Keuangan (OJK) through Roadmap for Sustainable Finance for creating the commitment to sustainable development in the banking sector and as the overall support of the financial services industry for sustainable growth resulting from the alignment of economic, social and environmental interests (POJK Nomor 51/POJK.03/2017).

The Green Economy concept covers various aspects that can be implemented in aspects of financial institutions, including green financing, green banking, green accounting, green product, green marketing, dan green behaviours (Mustofa et al., 2020), (Yuliawati, Rani, \& Assyofa, 2017), (Setiawan, Erawati, Dakhoir, \& Luqman, 2018), (Ali $\&$ Parveen, 2018). Triple Bottom Line aspects can be synergized with Islamic banking financial institutions that serves as intermediary institutions and able to support their operations to the environment, have responsibility and environmental performance as well as considering environmental protection aspects in maintaining their business which will coordinate with banking customers.

Although green banking already developed in the international banking system like bangladesh has implemented environmentally friendly financing targets for all banks, it is still not popular in Indonesia, $t$ is sill not popular in Indonesia. This concept emerged as a response to the demands of the global community asking the banking industry to actively participate in efforts to overcome the environmental crisis and increasing global warming. In particular, green banking means that banking sector no longer only focusing on its financial responsibility which managing its business as well as possible to generate the maximum profit for shareholders, but also must focus on its responsibility to preserve the 
environment and the universe (planet) and improve social welfare for the community (people).

In economics, the triple bottom line (TBL) maintains that companies should commit to focusing as much on social and environmental concerns as they do on profits. TBL theory posits that instead of one bottom line, there should be three: profit, people, and the planet. A TBL seeks to gauge a corporation's level of commitment to corporate social responsibility and its impact on the environment over time.

The essence of Green Banking in banking sector as a financial institution which in running its business is based on the principles of sustainable development. Especially in financing, namely the existence of ecological balance (environment), human welfare, and social and cultural development of the community. The Green Banking concept is implemented through various environmental-based service programs such as paperless, ebilling, e-banking, financing the environmental-based projects and the Go-Green program. Paperless program are banking services that aim to reduce paper consumption. By reducing paper consumption, it will indirectly reduce the amount of tree cutting as raw material for producing paper so that. Meanwhile, financing the environmental-based projects is a program that looks risks factors in the financing distribution, in this case it must prioritize environmentally friendly and sustainable businesses. If a business has fulfilled the environmentally friendly requirements according to the environmental impact analysis (AMDAL), then the new bank can disburse financing. Banks will see the extent of the risks that will arise and can be detrimental if they provide financing to businesses that are not environmentally friendly. Other environmental-based banking programs implemented by Bank Indonesia are contained in the Green Banking program.

Several studies have provided positive feedback in the application of green banking in the banking system which supports responsible financing to the environment. Therefore, banks must be able to consider policies from their products that are good for environmental sustainability banks (green product) (Handajani et al., 2019). Islamic banking in this case is very capable of implementing the concept of Green Banking because it has high visibility and tends to prioritize the involvement of social images in order to implement the concept of Green Banking. The involvement of banks in implementing the Green Banking concept also gives the bank a high reputation value because it is able to prove to the wider 
community its role as a financial institution that not only prioritizes profit but also considers and realizes good economic sustainability.

Thus, this study examines the concept of Green Banking at Bank Pembangunan Daerah in Indonesia, among others such as: PT. BPD Aceh Syariah, PT. BPD Sumatera Utara, PT. BPD Jambi, PT. BPD. Nagari, PT. BPD. Riau and Kepulauan Riau, PT. BPD Sumatera Selatan and Bangka Belitung. These institutions were chosen because they have work implementation programs that pay attention to economic and environmental sustainability. In this case, the concept of Green Banking is still foreign to banking stakeholders and also the public, where the role of Islamic banking must be optimized not only as a financial institution that implements a system based on sharia principles but also in line with these principles for economic sustainability that prioritizes ethics, morals, social values.

According to Authors Banking in Bangladesh, can be considered in implementing the Green Banking concept because Bangladesh has implemented environmentally friendly financing targets for all banks. Meanwhile, Islamic banking in Indonesia shows that the practice of Green Banking is still quite low which, from 2014-2017 Islamic banks in Indonesia excel in water management, paper, employee involvement in environmental commitments, while in carbon neutrality, waste management, environmental due diligence, environmental initiatives still need improvement (Indriyani, Burhany, \& Suhartanto, 2019).

Therefore, the authors are interested in developing research on Green Banking at Bank Pembangunan Daerah (BPD) in Indonesia, which consists of six BPD. The author is interested in conducting research on BPD because BPD is a regional-owned bank so that the concept of Green Banking is that BPDs can participate in implementing sustainable finance, especially Green Banking through their banking activities. The concept of Islamic Green Banking is considered in this study because it has been proven from previous research (Uddin, 2016) which stated that banking in Bangladesh 43 out of 56 banks had exposure to Green finance in their quarterly report then stated that Green Banking plays an important role in Islamic banking for environmental protection and sustainable development, through Green Banking allows investors to provide financing in environmentally friendly projects and at affordable prices. 


\section{REVIEW OF LITERATURE}

\section{Sustainable Finance}

The relationship between the economy and the environment has become an international concern, such as a report issued in 2013 by The World Economic Forum, both of which are related, namely that they can have a negative impact on the global economy as a result if industrial governance is not considered for its sustainability. The economy and the environment are an international agenda in the Sustainable Development Goals (SDGs) set by the United Nations (UN). The SDGs were prepared by the United Nations (UN) involving 194 countries, civil society and various economic actors from all over the world. This agendaand goals was created to answer the demands of world leadership in overcoming poverty, inequality, and climate change in the form of concrete actions, zero hunger, good health and well being, quality education, clear energy, decent work and economic growth, innovation and infrastructure (Prahara \& A'yuni, 2021); (Hayati, Neneng; Yulianto, Erwin, 2020).

Efforts to spur the country's economic growth that must pay attention to sustainability are the important role of financial service institutions. This has become a separate characteristic for banking Financial Services Institutions, where in the past period the parameters of success were financial gains. In contrast to the present and also the future is considered inadequate. For example, the global financial crisis in 2008 prompted financial sector reform by adding a success parameter in the form of contributing to financial system stability, especially in the area of strengthening capital and implementing Good Corporate Governance. Regulators, namely Bank Indonesia (BI) and the Financial Services Authority (OJK) strongly prioritize the development of environmentally friendly banking (Green Banking) (Hayati, Neneng; Yulianto, Erwin, 2020).

OJK collaborated with the Ministry of Environment to formulate a policy at the end of 2014 in the form of a Sustainable Finance Roadmap, which aims to provide a new standard for financial service institutions by applying the sustainability principle, namely the harmonization of the 3P (Profit-People-Planet) aspect in the business activities of financial services institutions. The Sustainable Finance Roadmap will serve as a reference for OJK, players in the financial services industry as well as the non-bank financial industry to the capital market which is under the supervision of the OJK as well as parties who have 
an interest in supporting sustainable development launched by the government. The launch of this Roadmap is a continuation of the program collaboration entitled "Green Banking" that was established between the Ministry of Environment and Bank Indonesia in 2010. Along with the birth of OJK, the Green Banking program was delegated by Bl, and the concept was expanded not only to banking, but also to financial service institutions (OJK, 2019).

The main mission of Sustainable Finance like Green Banking when it was first initiated is to change the paradigm in national development from a Greedy Economy to a Green Economy. Greedy Economy is a term where the focus of the economy is limited to economic growth which is assessed through the growth of Gross Domestic Product (GDP), exploitation of natural resources, and economic activities that rely on debt. Meanwhile, Green Economy is a change in perspective on economic development by taking into account the balance of the 3Ps, namely people (social), profit (economics) and planet (environment) (Alisjahbana \& Murniningtyas, 2018).

\section{Islamic Green Banking}

The concept of Green Banking is closely related to the term green financing. Green financing can be defined as a loan facility from a financial institution to a debtor engaged in the business sector that does not have an impact on decreasing the quality of the environment or social conditions of the community. However, Green Banking is not only focused on the world of financing, but also other programs that are environmentally sound (Nasution, 2018).

Specifically, Green Banking means that banks no longer only focus on responsibility financial management, namely managing its business as well as possible to generate the maximum profit for shareholders. The focus of his responsibilities is on efforts to preserve the environment and the universe as well as improve social welfare for the community. The combination of these three aspects into a report called a sustainability report. Sustainability reports are also known as Triple Bottom Line (TBL) or Triple P (People, Planet and Profit) reports. The TBL concept implies that banks must prioritize the interests of stakeholders (all parties). involved and influenced by the activities carried out by the company) rather than the interests of shareholders (Arifin, M Zainal, Sayuti, Noor Muhammad, 2020). 
Considerations in implementing Green Banking include: (i) Corporate Social Responsibility (CSR), carrying out activities in order to improve environmental quality and community empowerment or socializing green business. (ii) Financing: providing loans to environmentally friendly sectors or industries such as renewable energy, organic products, creative industries that utilize waste, high-end products, waste processing, as well as agriculture and forestry, providing interest incentives to debtors who have environmentally friendly business models, apply the principle of sustainability in the debtor's creditworthiness analysis in stages as part of the credit clause and is believed to be a distributor of two-step loans from global institutions for environmental projects. (iii) Funds: providing demand deposits, savings or time deposits affiliated with environmental community accounts (Arifin, M Zainal, Sayuti, Noor Muhammad, 2020); (Sun et al., 2020).

The practice of Green Banking is growing faster as a banking strategy in responding to the challenges of environmental problems. Banks play a role in providing funding for projects and investments that have the potential to cause environmental damage. Thus, the role of banks becomes crucial by considering environmental issues in providing financing. The company's efforts to actively implement environmental-related ideas facilitate companies to develop new practices or products among competitors, reduce costs, seize opportunities and become market leaders (Handajani, 2019).

Banks in Bangladesh found that the Green Banking regulatory guidelines issued by the central bank have a positive impact on the level of disclosure of Green Banking. This finding also reveals that bank good governance mechanisms such as institutional ownership and board size have a positive effect on the level of disclosure of Green Banking (Sharmeen \& Yeaman, 2020). Customer attention is also one of the factors that encourage Green Banking practices that can help banks to develop marketing strategies in the context of green innovation (Handajani, 2019). 
Framework

\section{Figure 1 \\ Theoretical Framework}

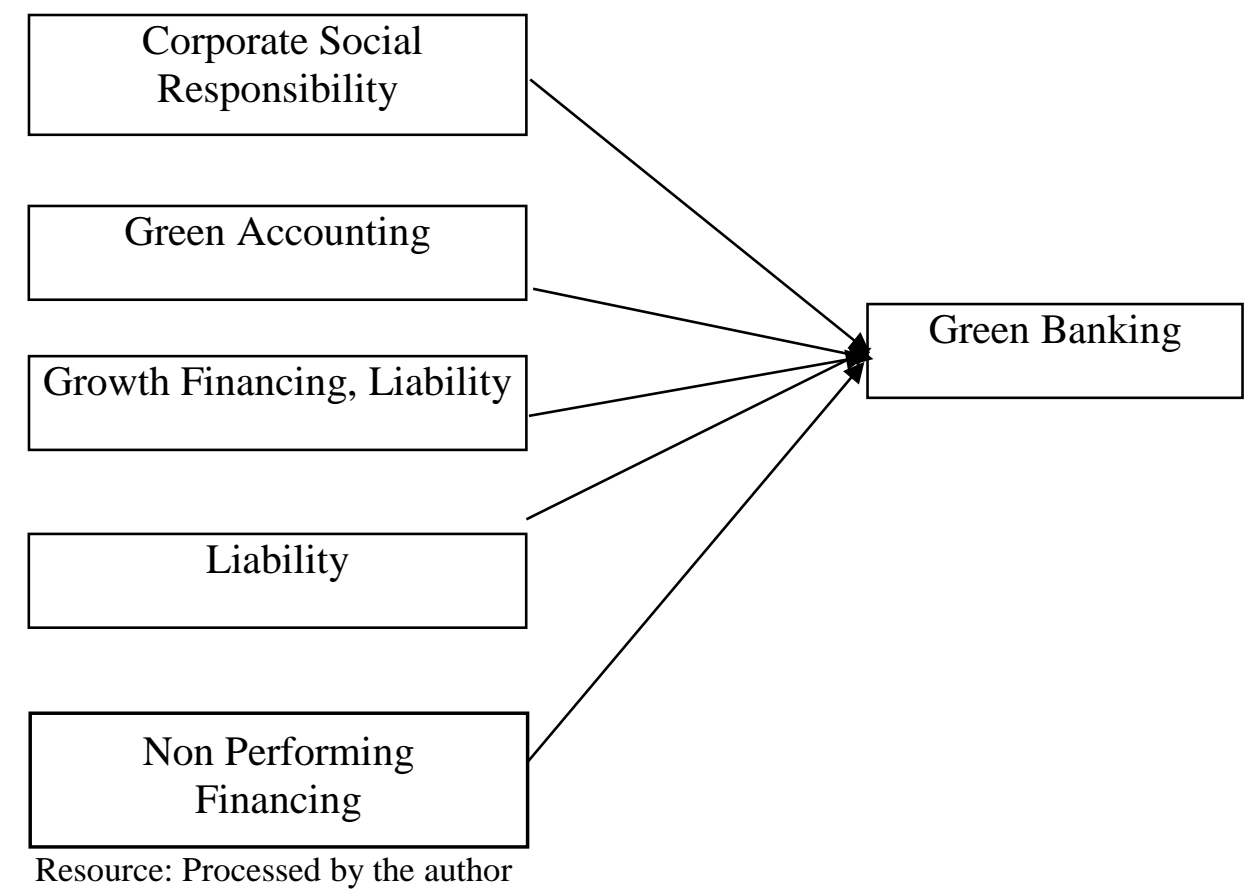

\section{Hypotesis}

$\mathrm{H}_{1}$ : There partial is influence of Corporate Social Responsibility, Green Accounting,

Growth Financing, Liability, Non Performing Financing On Green banking.

$\mathrm{H}_{2}$ : Three simultan is influence of Corporate Social Responsibility, Green Accounting, Growth Financing, Liability, Non Performing Financing On Green banking

\section{RESEARCH METHOD}

This research uses secondary data in the form of an annual report from 2015-2020 using a saturated sample, namely the entire population into the number of research samples from six financial institutions such as: PT. BPD Aceh Syariah, PT. BPD Sumatera Utara, PT. BPD Jambi, PT. BPD. Nagari, PT. BPD. Riau and Kepulauan Riau, PT. BPD Sumatera Selatan and Bangka Belitung. Descriptive data analysis technique is used to analyze data by describing the data that has been collected as it is (Sugiyono, 2017). The verification method aims to determine the causal relationship between variables through a hypothesis 
testing and statistical calculation so that results are obtained that show the hypothesis is rejected or accepted (Nazir, 2011).

\section{RESULTS AND DISCUSSION}

This section provides and discusses the findings of the study to several sub-sections, namely regression coefficients, coefficient of determination test $\left(\mathrm{R}^{2}\right)$, research hypotesis. In Following is the theoretical framework of this research:

As illustrated in Table 1, In the regression equation model, it is known that the constant value of 0.108 states that if the CSR, Green Accounting, Growth Financing, NPF, Liability variables are considered constant or equal to zero, then Green Banking default values is 0.108 . The regression coefficient value for the CSR variable in the regression equation shows a positive value of 0.325 , meaning that if CSR increase $1 \%$, Green Banking will increase by 0.325 . Green Accounting variable shows a negative value of 0.213, meaning that if Green Accounting value rise by one, Green Banking value decrease by $21.3 \%$. the same rule also applies to the Growth Financing which shows regression coefficient value -0.301, meaning that if Growth Financing value rise by one, Green Banking value decrease by $30.1 \%$. The regression coefficient value for the NPF variable in the regression equation shows a positive value of 3.416, meaning that if the NPF increases by one unit, Green Banking value will increase by $341 \%$. The regression coefficient value for the Liability variable in the regression equation shows a positive value of 0.191 , meaning that if Liability increases by one unit, then Green Banking has an increase of $19.1 \%$

Table 1

Multiple Linear Regression Test Results

\begin{tabular}{|c|c|c|c|c|c|c|c|}
\hline \multicolumn{8}{|c|}{ Coefficients $^{\mathrm{a}}$} \\
\hline \multirow{3}{*}{$\frac{\text { Model }}{\text { (Constant) }}$} & \multicolumn{2}{|c|}{$\begin{array}{l}\text { Unstandardized } \\
\text { Coefficients } \\
\end{array}$} & \multirow{2}{*}{$\begin{array}{l}\text { Standardized } \\
\text { Coefficients } \\
\text { Beta }\end{array}$} & \multirow[b]{2}{*}{$\mathrm{t}$} & \multirow[b]{2}{*}{ Sig. } & \multicolumn{2}{|c|}{$\begin{array}{l}\text { Collinearity } \\
\text { Statistics }\end{array}$} \\
\hline & $\mathrm{B}$ & $\begin{array}{l}\text { Std. } \\
\text { Error }\end{array}$ & & & & $\begin{array}{l}\text { Toler } \\
\text { ance }\end{array}$ & VIF \\
\hline & .108 & .036 & & 2.984 & .006 & & \\
\hline CSR & .325 & .110 & .386 & 2.953 & .006 & .689 & 1.452 \\
\hline $\begin{array}{l}\text { Green } \\
\text { Accounting }\end{array}$ & -.213 & .071 & -.391 & -3.016 & .005 & .701 & 1.426 \\
\hline
\end{tabular}




\begin{tabular}{llllllll} 
Growth & & & & & & & \\
Financing & -.301 & .118 & -.386 & -2.551 & .016 & .514 & 1.947 \\
NPF & 3.416 & .963 & .546 & 3.549 & .001 & .497 & 2.012 \\
Liability & .191 & .159 & .198 & 1.198 & .240 & .430 & 2.325 \\
\hline Source: SPSS output June 2021 & & &
\end{tabular}

Table 2 illustrates Coefficient of Determination $\left(\mathrm{R}^{2}\right)$ has a value of 0,647 or $64,7 \%$. The value of the coefficient of determination shows that the independent variables consisting of CSR, Green Accounting, Growth Financing, NPF, Liability to Green Banking are able to explain the dependent variable, which is $64.7 \%$, while the remaining $35.3 \%$ is explained by other variables that are not included in this research model.

Table 2

Coefficient of Determination Test Results Model Summary ${ }^{\text {b }}$

\begin{tabular}{llllll}
\hline & & & Adjusted & \multicolumn{3}{l}{ Std. Error of the } \\
Model & $\mathrm{R}$ & R Square & R Square & Estimate & Durbin-Watson \\
\hline 1 & $.804^{\mathrm{a}}$ & .647 & .588 & .06524 & 1.899 \\
\hline
\end{tabular}

a. Predictors: (Constant), Liability, Green Accounting, CSR, Growth Financing, NPF

b. Dependent Variable: Green Banking

Source: SPSS output, June 2021

Table 3 ilustrates research hypotesis that there simultan is influence of Corporate Social Responsibility, Green Accounting, Growth Financing, Liability, Non Performing Financing On Green banking. Based on , the probability value ( $\mathrm{Sig})$ is 0.000 . Because the value of sig $<0.05(0.000<0.05)$, then $H_{0}$ is rejected and $H_{1}$ is accepted. In conclusion, CSR, Green Accounting, Growth Financing, NPF, Liability have a simultaneous effect on Green Banking. As for another way of looking at this test, it can be compared between $\mathrm{F}_{\text {count }}$ and $\mathrm{F}_{\text {table. }} \mathrm{F}_{\text {table }}$ results obtained at alpha are $0.05, \mathrm{n}=36$ and $\mathrm{k}=6$ obtained from df 1 $=\mathrm{k}-1=5 ; \mathrm{df} 2=36-\mathrm{k}=30$ then the value of the $\mathrm{F}_{\text {table }}=2.53$ is obtained. Furthermore, comparing the value of $\mathrm{F}_{\text {count }}$ with $\mathrm{F}_{\text {table }}$ from the table above, it is known that the value of $F_{\text {count }}$ is 10.988 . So it can be concluded that $F_{\text {count }}>F_{\text {table }}(10.988>2.53)$, meaning that CSR, Green Accounting, Growth Financing, NPF, Liability have a simultaneous effect on Green Banking. 


\begin{tabular}{|c|c|c|c|c|c|}
\hline \multicolumn{6}{|c|}{$\begin{array}{c}\text { Table } 3 \\
\text { F Test Results } \\
\text { ANOVA }^{\text {a }}\end{array}$} \\
\hline Model & $\begin{array}{l}\text { Sum } \\
\text { Squares }\end{array}$ & Df & Mean Square & $\mathrm{F}$ & Sig. \\
\hline Regression & .234 & 5 & .047 & 10.988 & $.000^{\mathrm{b}}$ \\
\hline Residual & .128 & 30 & .004 & & \\
\hline Total & .362 & 35 & & & \\
\hline
\end{tabular}

a. Dependent Variable: Green Banking

b. Predictors: (Constant), Liability, Green Accounting, CSR, Growth Financing, NPF

Source: SPSS output, June 2021

Table 4 ilustrates research hypotesis that there partial is influence of Corporate Social Responsibility, Green Accounting, Growth Financing, Liability, Non Performing Financing On Green banking. The results of the SPSS coefficients output on the t-test and comparing the $t$ count with the $t$ table of 1.697 obtained from the $t$ table with $\mathrm{df}=\mathrm{n}-\mathrm{k}$ (366) which is 30 and alpha 0.05 . The following is a discussion of the partial test between CSR $\left(\mathrm{X}_{1}\right)$, Green accounting $\left(\mathrm{X}_{2}\right)$, Growth Financing $\left(\mathrm{X}_{3}\right)$, NPF $\left(\mathrm{X}_{4}\right)$, and Liability $\left(\mathrm{X}_{5}\right)$ on Green Banking (Y).

\section{The Influence of Each Variable can be Explained as Follows:}

The results of the t-test for CSR $\left(\mathrm{X}_{1}\right)$ on Green Banking (Y) show a Sig value of 0.006 and $t_{\text {count }}$ shows a value of 2,953 , meaning that the Sig value is smaller than the probability value $(0.006<0.05)$ and $t_{\text {count }}$ is greater than $t_{\text {table }}(2,953>1.697)$, then the conclusion that can be drawn is that $\mathrm{H}_{0}$ is rejected and $\mathrm{H}_{2}$ is accepted. This means that CSR has a partially significant effect on Green Banking.

The results of the t-test for CSR $\left(\mathrm{X}_{1}\right)$ on Green Banking (Y) show a Sig value of 0.006 and $t_{\text {count }}$ shows a value of 2,953 , meaning that the Sig value is smaller than the probability value $(0.006<0.05)$ and $t_{\text {count }}$ is greater than $t_{\text {table }}(2,953>1.697)$, then the conclusion that can be drawn is that $\mathrm{H}_{0}$ is rejected and $\mathrm{H}_{2}$ is accepted. This means that CSR has a partially significant effect on Green Banking.

The results of the t-test for Green Accounting $\left(\mathrm{X}_{2}\right)$ against Green Banking (Y) showed a Sig value of 0.005 and $t_{\text {count }}$ showed a value of 3.016. The value of sig is smaller than the probability value of $0.05(0.005<0.05)$ and $t_{\text {count }}$ is greater than $t_{\text {table }}(3.016<1.662)$, 
then the conclusion that can be drawn is that $\mathrm{H}_{0}$ is rejected and $\mathrm{H}_{2}$ is accepted. This means that Green Accounting has a significant partial effect on Green Banking. However, the direction of influence that appears is negative.

The results of the t-test for Growth Financing $\left(\mathrm{X}_{3}\right)$ on Green Banking $(\mathrm{Y})$ show a Sig value of 0.016 and $t_{\text {count }}$ shows a value of 2.551 . The value of sig is smaller than the probability value of $0.05(0.016<0.05)$ and $t_{\text {count }}$ is greater than $t_{\text {table }}(2.551>1.662)$, then the conclusion that can be drawn is that $\mathrm{H}_{0}$ is rejected and $\mathrm{H}_{2}$ is accepted. This means that Growth Financing (X3) has a partial significant effect on Green Banking. However, the direction of influence that appears is negative.

The results of the $t$ test for NPF $\left(\mathrm{X}_{4}\right)$ against Green Banking (Y) showed a Sig value of 0.001 and $t_{\text {count }}$ showed a value of 3.549. The value of Sig is smaller than the probability value $(0.001<0.05)$ and $t_{\text {count }}$ is greater than $t_{\text {table }}(3.549>1.697)$, then the conclusion that can be drawn is that $\mathrm{H}_{0}$ is rejected and $\mathrm{H}_{2}$ is accepted. This means that the NPF has a significant partial effect on Green Banking.

The results of the t-test for Liability $\left(\mathrm{X}_{5}\right)$ against Green Banking $(\mathrm{Y})$ showed a Sig value of 0.240 and $t_{\text {count }}$ showed a value of 1.198. The value of Sig is greater than the probability value $(0.240>0.05)$ and $t_{\text {count }}$ is smaller than $t_{\text {table }}(1.198<1.697)$, then the conclusion that can be drawn is that $\mathrm{H}_{0}$ is accepted and $\mathrm{H}_{2}$ is rejected. This means that Liability does not have a significant effect partially on Green Banking.

\section{Tabel 4}

t Test Result

Coefficients $^{\mathrm{a}}$

\begin{tabular}{|c|c|c|c|c|c|c|c|}
\hline \multirow[b]{2}{*}{ Model } & \multicolumn{2}{|c|}{$\begin{array}{l}\text { Unstandardized } \\
\text { Coefficients }\end{array}$} & \multirow{2}{*}{$\begin{array}{l}\text { Standardized } \\
\text { Coefficients } \\
\text { Beta }\end{array}$} & \multirow[b]{2}{*}{$\mathrm{t}$} & \multirow[b]{2}{*}{ Sig. } & \multicolumn{2}{|c|}{$\begin{array}{l}\text { Collinearity } \\
\text { Statistics }\end{array}$} \\
\hline & $\mathrm{B}$ & $\begin{array}{l}\text { Std. } \\
\text { Error }\end{array}$ & & & & $\begin{array}{l}\text { Toler } \\
\text { ance }\end{array}$ & VIF \\
\hline (Constant) & .108 & .036 & & 2.984 & .006 & & \\
\hline CSR & .325 & .110 & .386 & 2.953 & .006 & .689 & 1.452 \\
\hline $\begin{array}{l}\text { Green } \\
\text { Accounting }\end{array}$ & -.213 & .071 & -.391 & -3.016 & .005 & .701 & 1.426 \\
\hline $\begin{array}{l}\text { Growth } \\
\text { Financing }\end{array}$ & -.301 & .118 & -.386 & -2.551 & .016 & .514 & 1.947 \\
\hline NPF & 3.416 & .963 & .546 & 3.549 & .001 & .497 & 2.012 \\
\hline Liability & .191 & .159 & .198 & 1.198 & .240 & .430 & 2.325 \\
\hline
\end{tabular}




\section{The Effect of CSR on Green Banking}

This study suggests that in terms of the Green Banking policy at Bank Bangladesh, the Green Banking activities of Islamic Bank Bangladesh Limited (IBBL) have been concentrated in the following areas/sectors of daily activities: a) Investment Operations; b) Internal and Environmental Operations; c) CSR; d) Adoption of Green Technology Products; and e) Market Ecology.

The implementation of Green Banking at Bank Bangladesh is also supported by clear regulations with guidelines for Green Banking policies with BRPD Bank Bangladesh circular letter No. 02 dated February 27, 2011. Awareness of Bangladesh bankers and bank regulators in terms of implementing Green Banking thoroughly and effectively can be an example of the application of Green Banking in Indonesia. CSR or Bank activities are centered on the following points of view: a) Responsibility to shareholders; b) Responsibilities to employees; c) Responsibilities to customers; d) Responsibility to the community; e) Environmental responsibility.

\section{The Effect of Green Accounting on Green Banking}

The result Most banks have computerized their operations and have introduced online/internet banking platforms that reduce the customer's physical presence at the bank, thereby reducing the smoke and radiation that would be generated if the customer came by car to the bank or reducing his exposure to the bank. radiation from machines used by banks, among others. It will also ensure more people have access to basic banking services as a result of services such as mobile bank account opening due to digitalization support.

Research by (Setiawan et al., 2018) suggests that the application of Green Banking in Islamic banks is not only driven by Indonesian government policies, the application of Green Banking is also in accordance with Islamic values which are the philosophy and basic principles of Islamic banking. The impact of implementing Green Banking is a good environment and able to save energy and other operational costs. This is a form of sustainable development that includes three pillars, namely economic (profit), environment (planet), and social (human) which are in line with the concept of Green Banking. 


\section{The Effect of Growth Financing on Green Banking}

The result of the Bank using its position as project funder to ensure that only sustainable projects receive financing. When banks consider funding a project, they naturally assess and seek to reduce financial risk. Sustainable banking combines the evaluation of Environmental and Social Risks and the application of a comprehensive set of Environmental and Social guidelines to the decision to finance a project. Accordingly, the bank undertakes to provide loans to projects whose sponsors demonstrate the ability and willingness to comply with policies and guidelines aimed at ensuring that the project is socially responsible and complies with good environmental practices.

Research conducted by (Cahyadin et al., 2020) found that assets and financing tend to grow $60 \%$, meaning that Islamic banking still needs to encourage financing growth to the $100 \%$ level. The Bank's ability to manage assets is balanced with the ability to allocate and manage the financing. To implement digital and Green Banking, these conditions are important prerequisites that must be met. Islamic bank managers in Indonesia are also encouraged to innovate products and services that can increase the utilization of information technology readiness

\section{The Effect of NPF on Green Banking}

The Result must maintain healthy financing and reduce NPF levels so that bank productivity and sustainability last long term. NPF is a factor in increasing risk for Islamic banks so that Islamic banks not only consider their function in financing distribution but prioritize financing distribution with prudential banking principles.

\section{The Effect of Liability on Green Banking}

The first point is the benchmark for implementing digital and Green Banking. The position of readiness of Islamic banking in the application of digital and green banking can be a reference and evaluation of the extent to which they are able to achieve it. This can also be an input for Islamic banking to determine strategies for accelerating digital and Green Banking achievements. Acceleration can be done with a business linkage approach between Islamic banks in Indonesia. It is easier to share the use of digitalization and the ability to supervise financing that has a negative impact on environmental quality. In addition, sharing in organizational management that leads to Green Banking can also be realized. 
The second point is the efforts to realize efficient, reliable, and competitive sharia banking. The readiness position of Islamic banking also directs them to create an efficient, reliable, and competitive Islamic finance business. Increasing the use of Green Banking through digitalization is expected to more easily achieve business efficiency. In addition, increasing the ability to develop digitalization and control environmental impacts is expected to place Islamic banking as a reliable and competitive financial institution at the national, regional, and international levels.

The third point is the effort to prepare a digital index and Green Banking for sharia banking. The position of readiness of sharia banking can also encourage OJK to develop a digital banking index and sharia Green Banking. This is an important index for OJK and Islamic banking to evaluate and improve the digital and Green Banking achievements that have been achieved. In addition, OJK has instruments to help increase digital and Green Banking achievements in Islamic banking.

The fourth point is the effort to create a digital international center and Green Banking for sharia banking. The readiness of the Islamic banking position is also a parameter of their ability to realize Indonesia as a digital center and sharia Green Banking in the world. This effort will accelerate the domination of the Islamic financial market, especially in the domestic market. Indirectly, this action is also expected to shift the confidence of conventional banking customers to switch to Islamic banking. The assessment of the level of readiness for the application of digital and green banking by Islamic banking in Indonesia has the concept of goodness and benefit.

\section{The Green Banking Concepts in Qur'an Review}

(Arifin, M Zainal, Sayuti, Noor Muhammad, 2020) in their research suggests an integralist holistic picture of Islam about the environment that can be traced from the doctrine of the Qur'an through the term category of environmental damage. The beginning of the emergence of the concept of Green Banking due to environmental damage is now increasingly happening. The participation of banking institutions in realizing this go green turned out to have a strong foundation on the meaning of the Qur'an.

The Qur'an has various terms, among the terms in the Qur'an that are directly related to environmental damage is the term fasad, which is repeated 50 times in the Qur'an. The short meaning is something that is not balanced. The scope of the meaning of 
the fasad turns out to be quite broad, namely regarding the soul / spirit, body, and everything that deviates from the balance / what should be. The term fasad in the Qur'an can be classified with several meanings, First, it is interpreted as shirk and immorality. This can be proven in QS Al-A'raf [7]: 56, in this verse it is interpreted as shirk and immoral acts.

First, it can also be interpreted as deviation or out of order as in QS Al-Anbiya [21]: 22. Second, it can mean damage or tear down (تخريب) as in QS An-Naml [27]: 34. Third, it means environmental damage that causes damage to the environment. It is explained in QS Al-Baqarah [2]: 205 and QS Ar-Rum [30]: 41 That is the hypocrisy of human nature (turning away from Him) to do damage on earth to plants and livestock in a deliberate way. Taking into account the above interpretation, the term fasad in the Qur'an can be divided into several categories, namely (1) deviant and unhelpful behavior; (2) disorder/chaos; (3) Destructive behavior; (4) Environmental damage.

According to Yusuf al-Qardhawi, protecting the environment is the same as protecting religion, protecting the soul, protecting the mind, protecting offspring, and protecting wealth. The reason is, if the aspects of religion, soul, mind, lineage, and property are damaged, then human existence in the environment will be tarnished. The concept of environmental fiqh (fiqh al-bi'ah) formulated by scholars reflects the dynamics of fiqh related to changing contexts and situations (Al-Qardhawi, 2001). Facing environmental problems, the Indonesian Ulama Council also contributed by issuing a fatwa on environmental sustainability. Some examples of fatwas are: a) DSN-MUI Fatwa Number 22 of 2011 concerning Environmentally Friendly Mining; b) DSN-MUI Fatwa Number 30 of 2016 concerning the Law on Forest and Land Burning and its Control; c) DSN-MUI Fatwa Number 47 of 2014 concerning Waste Management to Prevent Environmental Damage.

To achieve this, a global commitment is needed, in this case, Islamic banking has the main function as a collector and distributor of public funds. However, Islamic banking in its participation in providing development financing must still pay attention to the principle of prudence. The aim is to support the implementation of national development in order to increase equity, economic growth, and national stability towards improving people's welfare. Environmentally sound project financing has proven to be able to increase 
competitiveness and provide distinct advantages for banks that implement it as a business strategy.

Islamic banks must be at the forefront of implementing current green banking policies. A number of Islamic banks have actively provided financing for new and renewable energy development efforts, financing for industrial energy efficiency improvements, and environmentally friendly integrated agricultural financing. Green Banking at Islamic banks is based on a project or business financing strategy that is environmentally and socially friendly that targets environmental preservation and social stability of the community through efficiency and paper less or more practically using online (digital) applications (Radyati \& Hamidah, 2014).

Currently, 6 Regional Development Banks (BPD) in North Sumatra Province, namely Bank Aceh, Bank Sumut, Bank Jambi, Bank Nagari, Bank Riau, Bank Sumsel, and Babel have begun to implement Green Banking through the implementation of digital banks because these banks use banking services. technology-based finance is seen from the annual report data presented and based on the bank's financial service process that has a real-time system and in terms of cost efficiency as reflected in each BPD, namely from the application of green accounting and growth financing. Judging from the 6 BPDs that disburse a lot of CSR funds in the environmental and economic fields, namely PT Bank Sumut.

The implementation of Green Banking has also started to be implemented by Bank Aceh through low-cost stationery at the bank (ATK), while Bank Sumut uses digital banking the same as Bank Aceh and Bank Jambi which have started digital transformation from 2017-2020. Meanwhile, Bank Riau as in 2015 - 2016 distributed CSR funds which were dominated by social activities. Bank Sumsel and Babel have a CSR program, namely distribution to MSMEs through MSME partners since 2019. For Bank Nagari, digital transformation has been carried out since 2019-2020.

Overall, the Bank can carry out Green Banking with Green credit cards, Green checking accounts (converting checking accounts to online banking), Green CDs (bonus level for online banking), Green savings accounts, Green money market accounts (converting savings accounts to online banking)), green loans (better rates for energy 
efficiency projects) and green mortgages (better rates for energy-efficient homes) (Afroz, 2017).

\section{CONCLUSION}

This Study Proves that one liability has No. effect on green banking The strength of this study is using various references that are strongly related to the implementation of Green Banking in other countries which are the motivation for Islamic banking in Indonesia to apply the concept of Green Banking because it is not easy to implement Green Banking in Islamic banking in Indonesia, especially in the Sumatra region. There are few banks that can be used as samples. The testing period in this study is $2015-2020$. Further research is expected to increase the number of samples that are observed and the testing period, then it is expected to use other variables outside of this research model. This research can be a reference for further research.

\section{REFERENCE}

Aasa, O. P., Adepoju, T. F., \& Aladejebi, O. (2016). Sustainable Development through Green Innovative banking 3p's. International Journal of Innovative Research \& Development, 5(14), 100-112.

Afroz, N. N. (2017). Green Banking Initiatives of Islamic Bank Bangladesh Limited. Global Journal of Management and Business Research, 1(1), 1-8.

Ali, Q., \& Parveen, S. (2018). Islamic Bankers Green Behaviours and Its Impact on Green Banking Growth. Asia Proceedings of Social Sciences, 1(4), 80-84. https://doi.org/10.31580/apss.v1i4.289

Alisjahbana, A. S., \& Murniningtyas, E. (2018). Berkelanjutan Di Indonesia:

Arifin, M Zainal, Sayuti, Noor Muhammad, E. al. (2020). Green Banking Concepts in Qur'an Review. International Journal of Nusantara Islam, 08(012020), 98-109.

Bouteraa, M., Raja Rizal Iskandar, bin R. H., \& Zainol, Z. (2020). Green Banking Practices from Islamic and Western Perspectives. International Journal of Business, Economics and Law, 21(5), 1-11.

Cahyadin, M., Sarmidi, T., \& Nurrachma, E. A. (2020). The Readiness of Islamic Banking in Indonesia to Implement Digital and Green Banking. Jurnal Ekonomi Pembangunan: Kajian Masalah Ekonomi Dan Pembangunan, 20(2), 176-192. https://doi.org/10.23917/jep.v20i2.6757

Hamdani, A. \&. (2019). Jurnal Presipitasi. Jurnal Presipitasi, 16(3), 133-139. 
Handajani, L. (2019). Corporate Governance dan Green Banking Disclosure: Studi pada Bank di Indonesia. Jurnal Dinamika Akuntansi Dan Bisnis, 6(2), 121-136. https://doi.org/10.24815/jdab.v6i2.12243

Handajani, L., Rifai, A., \& Husnan, L. H. (2019). Study of The Initiation of Green Banking Practices at State-owned Bank. Jurnal Economia, 15(1), 1-16. https://doi.org/10.21831/economia.v15i1.21954

Hayati, Neneng; Yulianto, Erwin, Y. S. (2020). Jurnal Akuntansi Bisnis dan Ekonomi. Peranan Keuangan Berkelanjutan Pada Industri Perbankan Dalam Mendukung Suistainable Develpoment Goals, 6(1), 1633-1652.

Indriyani, R., Burhany, D., \& Suhartanto, D. (2019). Green Banking Practice of Indonesia's Islamic Banks. (February 2020). https://doi.org/10.4108/eai.6-122018.2286307

Istiowati, S. I. (2018). Analisis Strategi Pembiayaan Dalam Upaya Optimalisasi Konsep Green Finance (Studi Kasus Pada Bank Rakyat Indonesia Syariah Kantor Cabang Malang). Jurnal Ilmu Manajemen Advantage, 2(1), 223-238. https://doi.org/10.30741/adv.v2i1.285

Khan, Yahya \& Szegedi, K. (2019). The Concept Of Green Banking In Pakistan. 5(2), 6.

Malinton, Devi \& Kamp, K. (2019). Pengaruh Moderasi Green Banking Dalam Hubungan Antara Corporate Social Responsibility Dan Going Concern. Journal of Chemical Information and Modeling, 53(9), 1689-1699.

Moch, O., \& Nurdin, A. (2019). Green Product and Green Marketing for Green Banking. September 2018.

Muhammad Hussain Qureshi, \& Talat Hussain. (2020). Green Banking Products: Challenges and Issues in Islamic and Traditional Banks of Pakistan. Journal of Accounting and Finance in Emerging Economies, 6(3), 703-712. https://doi.org/10.26710/jafee.v6i3.1177

Mustofa, U. A., Nia, R., Putri, A., Kurniawan, M., Fikri, M., \& Kholid, N. (2020). Green Accounting Terhadap CSR pada Bus di Indonesia dengan Kinerja Keuangan Sebagai Variabel Intervening. 6(03), 508-520.

Nasution, R. (2018). Sinergi Dan Optimalisasi Green Banking Perbankan Syariah Dalam Mewujudkan Suistainable Finance. EKONOMIKAWAN: Jurnal Ilmu Ekonomi Dan Studi Pembangunan, 18(1), 34-52. https://doi.org/10.30596/ekonomikawan.v18i1.2151

Nazir, M. (2011). Metode Penelitian. Bogor: Ghalia Indonesia.

OJK. (2019). Roadmap Keuangan Berkelanjutan di Indonesia. Roadmap Keuangan Berkelanjutan Di Indonesia, 138-155. 
Prahara, R. S., \& A'yuni, D. S. (2021). Corporate Social Responsibility As a Corporate Green Accounting Implementation. Indonesian Interdisciplinary Journal of Sharia Economics (IIJSE), 3(2), 178-185. https://doi.org/10.31538/iijse.v3i2.1216

Pusva, I. K. E. D. (2017). Analisis penerapan.

Setiawan, H., Erawati, D., Dakhoir, A., \& Luqman, L. (2018). A Green Banking for Sustainable Development in Sharia Banking. (Ancosh), 82-86. https://doi.org/10.5220/0007415700820086

Siahaan, C., Silalahi, A. S., Sianipar, A. S., Non-tunai, T., Banking, G., Modal, K., \& Bermasalah, K. (2018). Analisis Implementasi Green Banking Sustainability dan Kinerja Keuangan Terhadap Profitabilitas Perbankan yang Terdaftar Di Bursa Efek Indonesia Tahun 2012-2018.

Sun, H., Rabbani, M. R., Ahmad, N., Sial, M. S., Guping, C., Zia-Ud-din, M., \& Fu, Q. (2020). Csr, co-creation and green consumer loyalty: Are green banking initiatives important? A moderated mediation approach from an emerging economy. Sustainability (Switzerland), 12(24), 1-22. https://doi.org/10.3390/su122410688

Sugiyono. (2017). Metode Penelitian Kuantitatif, Kualitatif dan R\&D. Bandung: CV. Al Fabeta.

Uddin, M. N. (2016). 'Shari'ah' Based Banking and Green Financing: Evidence from Bangladesh. Journal of Emerging Economies and Islamic Research, 4(2), 79. https://doi.org/10.24191/jeeir.v4i2.9088

Uddin, M. N., \& Ahmmed, M. (2018). Islamic Banking and Green Banking for Sustainable Development: Evidence from Bangladesh. Al-Iqtishad: Jurnal Ilmu Ekonomi Syariah, 10(1), 97-114. https://doi.org/10.15408/aiq.v10i1.4563

Yuliawati, T., Rani, A. M., \& Assyofa, A. R. (2017). Efektivitas Implementasi Green Financing Sebagai Alternatif Pembiayaan Berkelanjutan Bagi UMKM Sektor Industri Pengolahan Alas Kaki Di Kota Bandung. Jurnal Manajemen Dan Bisnis (Performa), XIV(2), 152-162. 